\title{
A Preliminary Study on Grazing Pattern of Sheep Transhumance in Turkey
}

\author{
Sezen Ocak Yetişgin ${ }^{1, a}$, Şeyma Aydemir ${ }^{2, b, *}$ \\ ${ }^{1}$ Department of Animal Science, Faculty of Agriculture, Ondokuz Mayls University, 55139 Kurupelit/Samsun, Turkey \\ ${ }^{2}$ Veterinary Department, Alaca Avni Çelik Vocational School, Hitit University, 19600 Çorum, Turkey
}

*Corresponding author

\begin{tabular}{l|l}
\hline A R T I C L E I N F O & A B S T R A C T \\
\hline Research Article & $\begin{array}{l}\text { Grazing activities of indigenous sheep breed of the Turkish breed Karakaş and Koçeri which were } \\
\text { transhumance flocks were investigated in a typical unimproved mountainous pasture in the East of } \\
\text { Turkey. Data were collected from two different flocks on main daily activities (grazing, resting, } \\
\text { moving or standing) every fifteen minutes. The characteristics of the pastures around the routes were } \\
\text { assessed according to CORINE Land Cover classification system. Standing was a residual activity } \\
\text { in both study paths. The animals concentrated their activity mostly on grazing while resting and } \\
\text { moving occurred in specific times during the whole grazing period. Once the animals were heading } \\
\text { back to their main settlement areas to be milked, grazing activity have been increased. Further studies } \\
\text { on grazing behavior and changes in land cover will help to adjust the management strategies to the } \\
\text { available natural resources. }\end{array}$ \\
Accepted : $02 / 09 / 2019$ &
\end{tabular}

Natural resources

Grazing behavior

Sheep

Transhumance

Turkey

Türk Tarım - Gıda Bilim ve Teknoloji Dergisi 7(10): 1629-1634, 2019

\section{Türkiye'de Konar Göçer Koyun Sürülerinde Otlama Davranışları Üzerine Ön Araştırma}

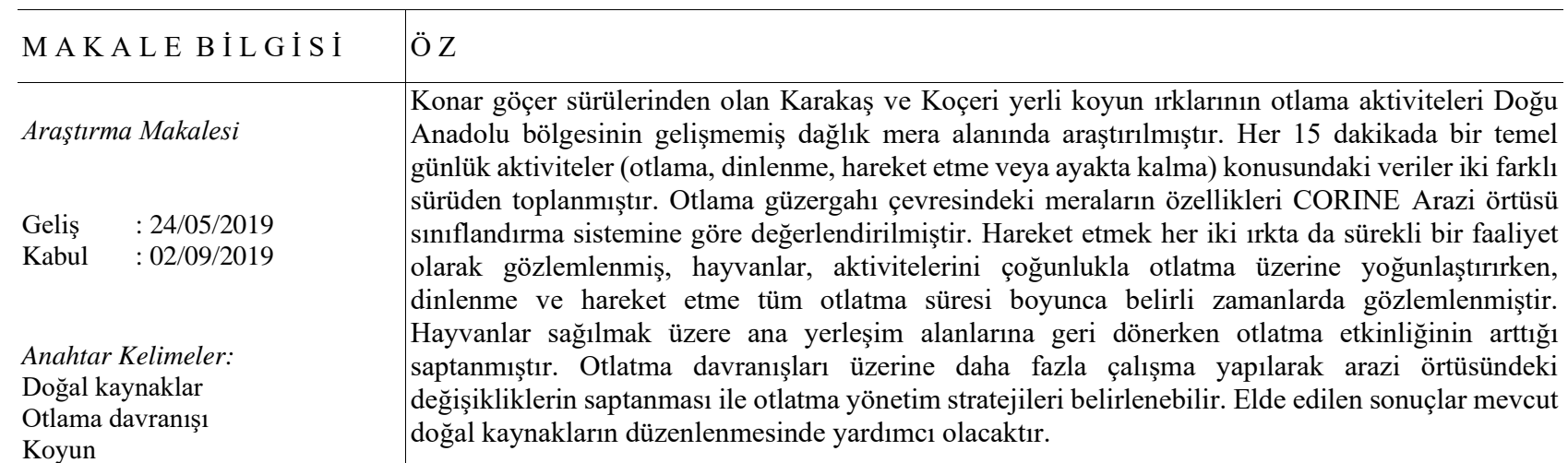

Koyun

Konar göçer

Türkiye

\begin{abstract}
Konar göçer sürülerinden olan Karakaş ve Koçeri yerli koyun ırklarının otlama aktiviteleri Doğu Anadolu bölgesinin gelişmemiş dağlı mera alanında araştırılmıştır. Her 15 dakikada bir temel sürüden toplanmıştır. Otlama güzergahı çevresindeki meraların özellikleri CORINE Arazi örtüsü sınıflandırma sistemine göre değerlendirilmiştir. Hareket etmek her iki ırkta da sürekli bir faaliyet Hayvanlar sağılmak üzere ana yerleşim alanlarına geri dönerken otlatma etkinliğinin arttığ saptanmıştır. Otlatma davranışları üzerine daha fazla çalışma yapılarak arazi örtüsündeki doğal kaynakların düzenlenmesinde yardımcı olacaktır.
\end{abstract}




\section{Introduction}

Grazing is the most important daily activity that ruminant livestock undertake. The ability to detect and understand the grazing patterns of free-ranging livestock is critical for monitoring the weight gain of individual animals, managing available biomass within the landscape (Delagarde and Lamberton, 2015; Ueda et al., 2011) and taking crucial decisions regarding to natural grassland management and conservation. Mountainous pastures, which located up to 600 $\mathrm{m}$, are characterized by a rough topography and great variability of plant communities and herbage cover (Aldezabal et al., 1999). Their flora composed mainly by perennial grasses and glass-like plants as well as of some forbs and shrubs. They are grazed seasonally, from mid- spring to autumn, while they are covered by snow during winter (Sarlis, 1998). Grazed pastures represent a specific, but synthetic ecological system with crucial dependent variables such as nutrition and environmental controls influencing the dominant plant and animal species (Squires, 1975). In recent years, it has been increasingly realized that grazing of sheep considerably contributes to a sustainable management of agricultural areas and to landscape preservation (Brüne and Stumpf, 2004; Fischer et al., 2007).

Rangelands (dominated by dry grasslands and grass/shrublands) cover 22.9 million ha in Turkey (Koc et al., 2015) and seasonal grazing have been historically the way of livestock production. These grasslands are still critically important to livestock production, an activity which contributes to $12 \%$ of the agricultural output in Turkey, accomplished in small-scale farms in which domestic breeds with low productivity but high adaptation to the harsh environmental conditions are managed (FAO, 2016). However, as a result of the implementation of poor agricultural policies, such as convention of rangeland to cropland and failure to prevent the encroachment of urbanization (Sayar et al., 2015). According to Sabanci, (2012), the rangeland area have been decreased by approximately 37 million hectares between 1950s and 2000s. The existing sheep production systems in Turkey are based on traditional grazing of communal grasslands that provides free herbage for animals during 6 months in a year which has been a traditional way of production since hundreds of years in Turkey-still surviving, yet with many challenges and constrains. Anatolian highlands have been exposed to systematic grazing over the last ten thousand years by a high degree of variability in degree of mobility, land use and animal preferences and herd management strategies (Hammer and Arbuckle, 2017). On the other hand, the system also provides numerous ecological and social contributions. Since grasslands in the mountains are the only free feed available areas-they are very attractive for farmers for minimum input production and thus high in economic returns. However, high stocking rates cause extensive degradation of grasslands, threating sustainability and vigour of the forages in these pastures if wrongly managed.

Turkey has around 31 million sheep (FAO, 2016) and majority of them are still linked to seasonal transhumance production systems. Those sheep flocks have been adopted since millennia to the unique pastoral areas and landscapes with conservation value which prevail in the Eastern (sheep transhumance) and Mediterranean region (goat transhumance) of Turkey. There are scarce studies which have tackled transhumant sheep grazing patterns in relation with landscape characteristics in a given moment in these rangelands. There are different systems adapted to several regions, yet no studies have been conducted on their grazing patterns under natural conditions. This paper aimed to describe the nocturnal grazing behaviour of sheep flocks' during summer period in the Eastern of Turkey. Assessing their grazing behaviour within a specific landscape context is a key aspect to develop appropriate management systems which maximize animal performances while controlling environmental impact.

\section{Materials and Methods}

\section{Study Site}

The study was conducted in Erzurum and Ağr1 provinces in East Anatolia, Turkey (Figure 3) during the year 2017 on Koçeri and Karakaş local breeds (Figure 1, Figure 2).

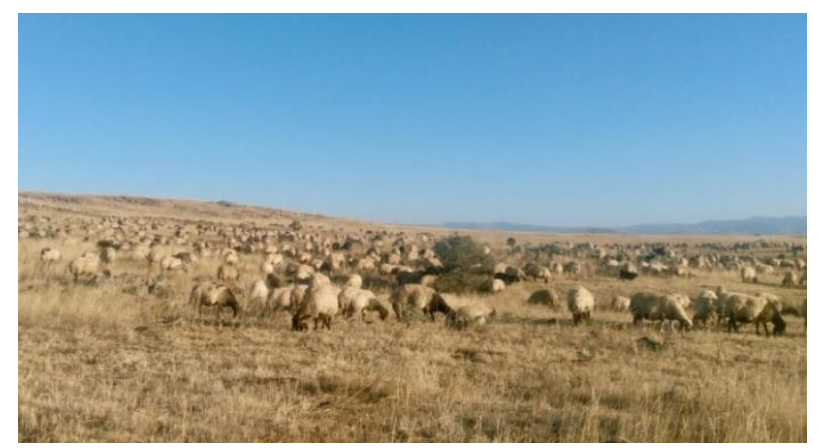

Figure 1 Koçeri breed in unimproved mountain pasture of Ağrı province
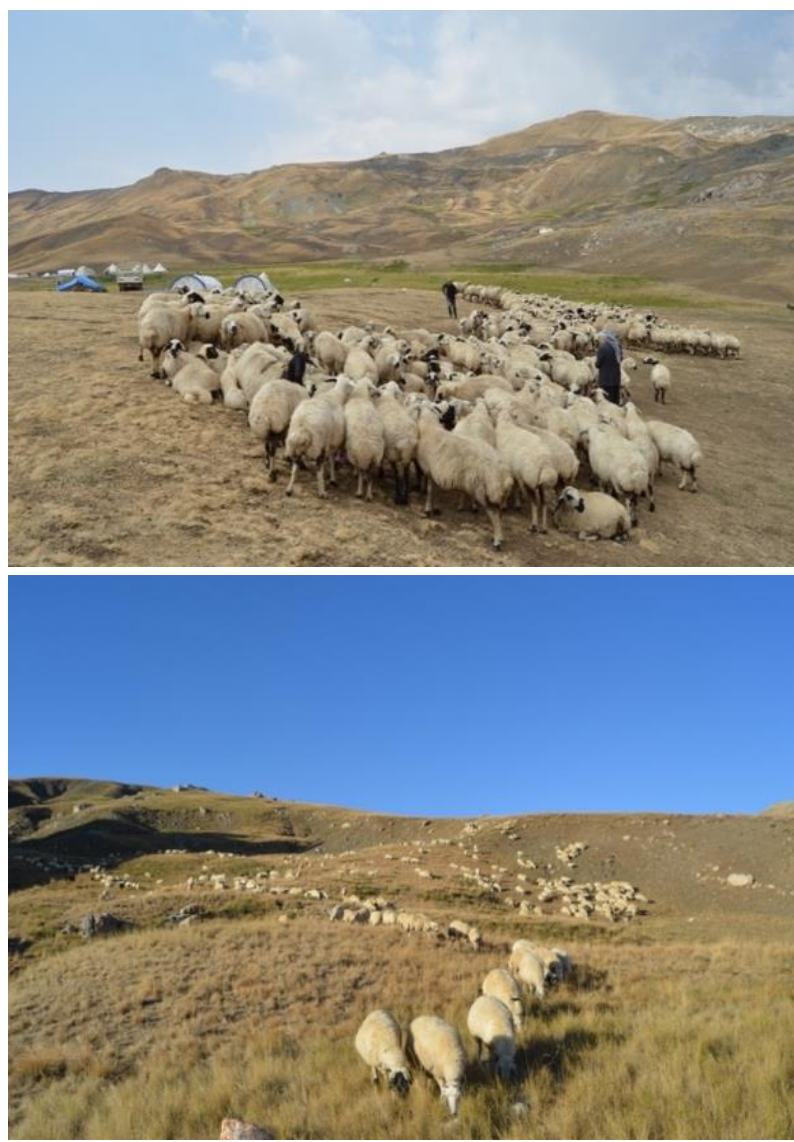

Figure 2 Karakaş breed in Erzurum mountain pastures 


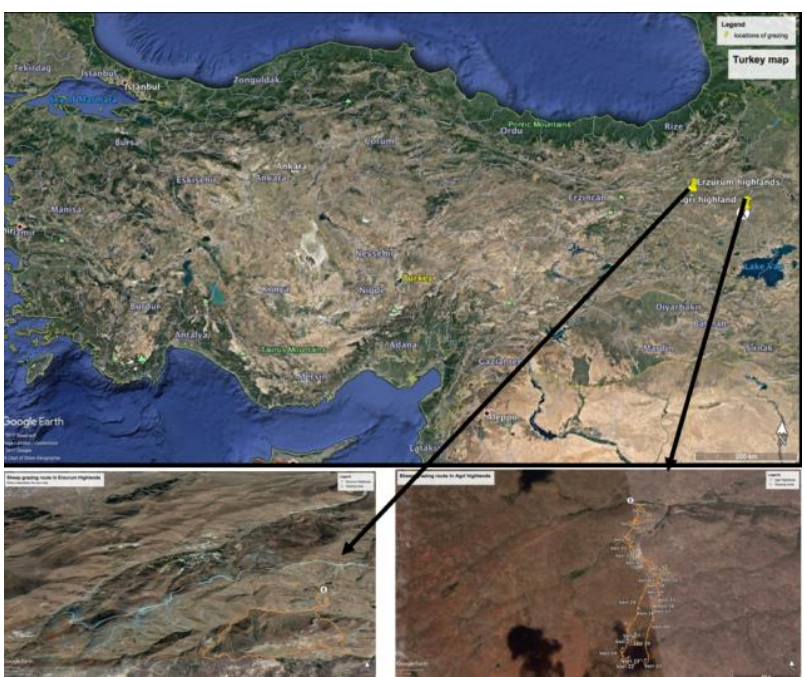

Figure 3 Location of study sites in Turkey

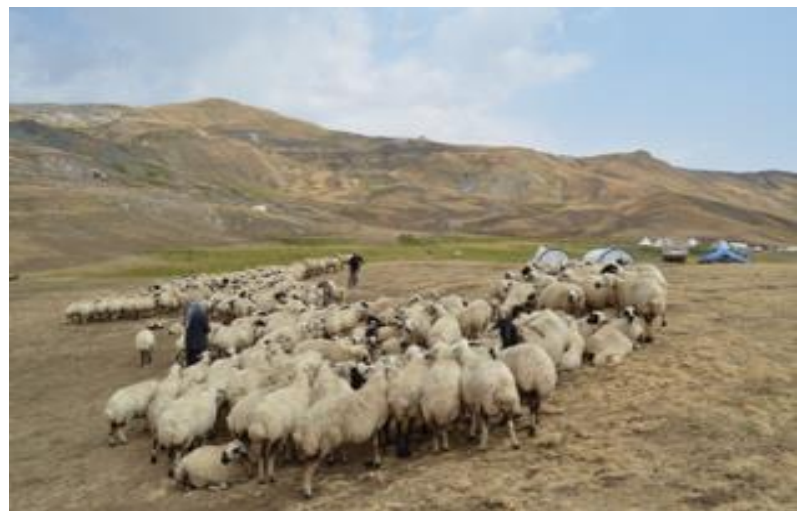

(a)

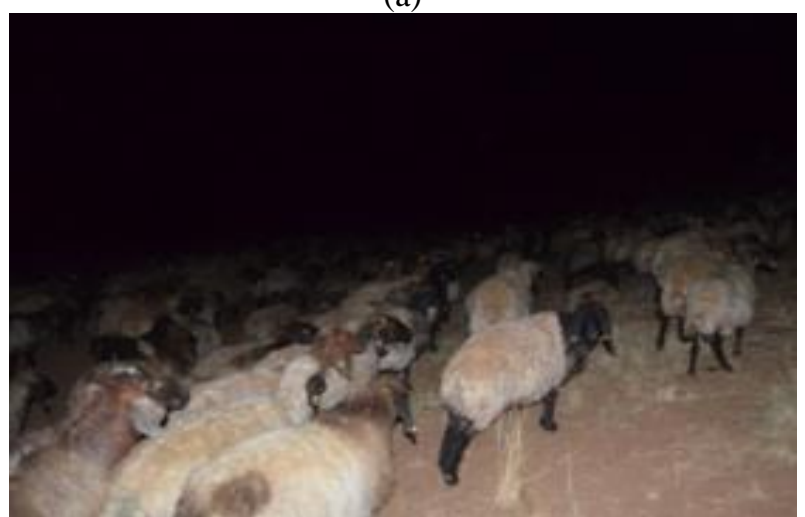

(b)

Figure 4a Karakaş sheep in Erzurum highland, 4b Koçeri sheep in Ağrı highlands

The pastures in the mountain elevating from 1975-2062 $\mathrm{m}$ in Ağr1 and 2503-2810 $\mathrm{m}$ in Erzurum. The climate of the whole area is continental with long winters and cold limiting dormant-season grazing to south-facing slopes. According to the meteorological station at nearest, the mean annual temperature was recorded $16.6^{\circ} \mathrm{C}$ and the total regional annual precipitation ranged between $400 \mathrm{~mm}$ and $650 \mathrm{~mm}$, and it intensifies from autumn through spring. Vegetation cover is dominated by cool-season grasses that are dormant during the summer, especially in August and early September. The mountain steppe has a dense coverage of short grasses, mainly sheep fescue and some legumes.
The composition of Ağrı Tutak Döşkaya pasture was composed of; Medicago spp., Onobrychis sativa, Dactylis glomerata, Koeleria cristata, Agropyron spp., Festuca ovina, Astragalus spp., Poa bulbosa, Bromus tectorum, Astragalus spp., Achillaa millefolium, Eryngium campestre, Centaurea kilaea, Saponaria officinalis and Anthemis (Anonim, 2017). The botanical composition of Erzurum pastures determined as; Ori ganum onites, Melitotus Officinalis, Onorbrychis sp., Poa Pratensis, Lotus corniculatus, Pona pila, Dactylis glomerata L. Astragalus membran aceus, Verbascum Thapsus (Anonim, 2017a).

\section{GIS Route}

The routes of the flock were recorded via Wikiloc ${ }^{\circledR} 2017$ and transferred to Google Earth. The land cover surrounding each pastureland $(25 \mathrm{~km}$ radius) was analyzed according to CORINE Land Cover classification (Büttner et al., 2012) and a vector based geographic information system, ArcGis 10.3 (ESRI, 1996).

\section{Sampling and Experimental Analysis}

Data were recorded in the summer settlement areas of transhumants in the eastern highlands of Turkey. Two transhumant flocks were followed on foot in order to record daily grazing routes and patterns of Koçeri (Fig 4b) and Karakaş (Fig 4a) breeds in August 2017. Karakaş and Koçeri are indigenous multipurpose fat tail Turkish breeds.

Average flock size for both flocks were approximately 400 ewes. 20-23 ewes of each flock were randomly selected and marked during data recording. Grazing activities of 20 to 23 sheep of each flock were observed every 15 minutes by 2 trained observers in each location equipped with hand chronometers and cameras and the number of animals which were grazing, walking, standing and resting activities were recorded in every $15 \mathrm{~min}$. Grazing in the eastern pastures are performed mainly at night due to belief that cooler temperatures are more suitable for grazing according to the local shepherds. Therefore observations were made from $19.00 \mathrm{pm}$ to 8.15 am as normal grazing practice. Grazing activities were recorded as grazing time (grazing or browsing while walking or standing), resting (simply sitting for rest), moving (simply walking, running) and standing (simply standing doing nothing). Grazing patterns were recorded five consecutive days in each location. The shepherds were interviewed before and after the routes in order to gather information about their management strategies. The shepherds made two breaks (one before mid-night and one after midnight - for eating and resting) in each location. During these breaks flocks stay close to each other and rest as well. Head lamps were used by the observers in order the record the behaviours yet in a certain distance in order to not interfere their natural grazing patterns. The average distances covered by the flocks during their daily routes were recorded as 6.3 and $8.4 \mathrm{~km}$ in Ağr1 and Erzurum, respectively. Maximum and minimum altitudes were reached at $2062 \mathrm{~m}$ and $1975 \mathrm{~m}$ in Ağr1 and at $2801 \mathrm{~m}$ and $2503 \mathrm{~m}$ in Erzurum, respectively. Chi square test were used in order to test the dependency between the variables. 


\section{Results and Discussions}

With the movement of the herds, more moving activities observed than grazing. Grazing activity started after 1-2 hours of walking for both herds. Grazing was the main activity $(55.4 \%)$ followed by moving $(18.5 \%)$ during each observation in both study sites, while resting and standing were recorded only in $10-13.8 \%$ of the sheep in each occasion. Shepherds stopped twice to rest and most of the animals lie down during those two periods in both areas. Majority of the animals intensified grazing after midnight (00.30 am), more intensified around $5.30 \mathrm{am}$. The grazing activity intensified in three periods along the night in Erzurum although 5:45 am onwards most of the animals focused on this activity. The moving activity increased in several periods during night and some of them with a decrease in grazing. The resting frequency fluctuated and increased in two occasions whereas it was a minority activity by the end of the routes (Figure 5, Figure 6). The standing activity was inconsistent with a little peak between 21:15 pm and 21:30 pm (Figure 5).

Grazing intensified during early day time in Ağrı (Table 3). Similarly, Loridas et al., 2011 found higher grazing time of sheep in the highlands. With regards to the night grazing or grazing in the cool hours, there is an agreement with Shinde et al., 1997 that ruminants tend to avoid grazing during the hot hours of the day and thus reducing their daily grazing time. Resting had two peaks between 20:45 pm21:30 pm and 2:30 am and 2:45 am. The standing activity was scarce with no remarkable peaks (Figure 6).

The flocks moved across a landscape dominated by natural grasslands (especially in Erzurum) followed by sparsely vegetated areas in both areas. Nevertheless, the relevance of other land covers was variable in each case (Table 1). Regarding Ağr1 path, the main land covers (agglutinating around $75 \%$ of all surfaces) natural grasslands, sparsely vegetated areas, arable land and salines. As for Erzurum path, landscape is dominated by natural grassland, sparsely vegetated areas and transitional woodland-scrubland. Forests were more abundant in the Erzurum surroundings (6\%).

Land use devoted to agriculture and arable land cover a wider surface in Ağr1 than in Erzurum mountains. These marginal territories offer limited options but enough for small ruminants which had lower nutritional requirements. An alternative production systems such as livestock grazing of bigger species like cattle or horses could be unfeasible (García et al., 2013).

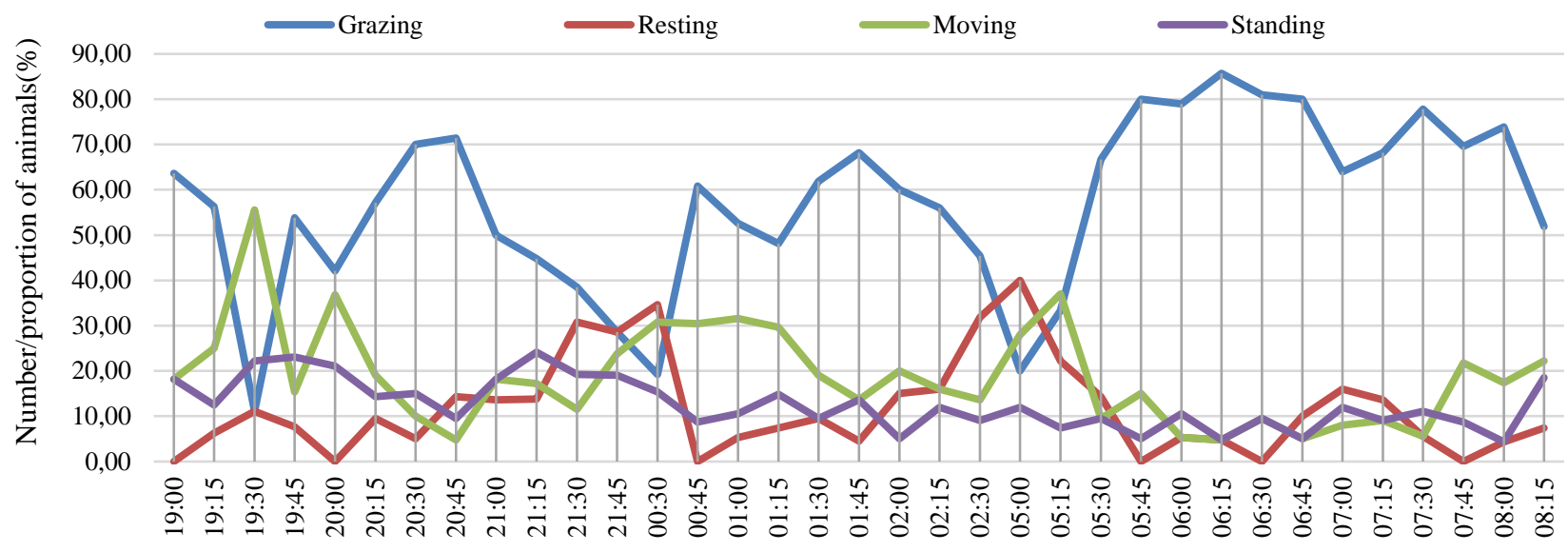

Time

Figure 5 Daily variation of grazing patterns in Erzurum

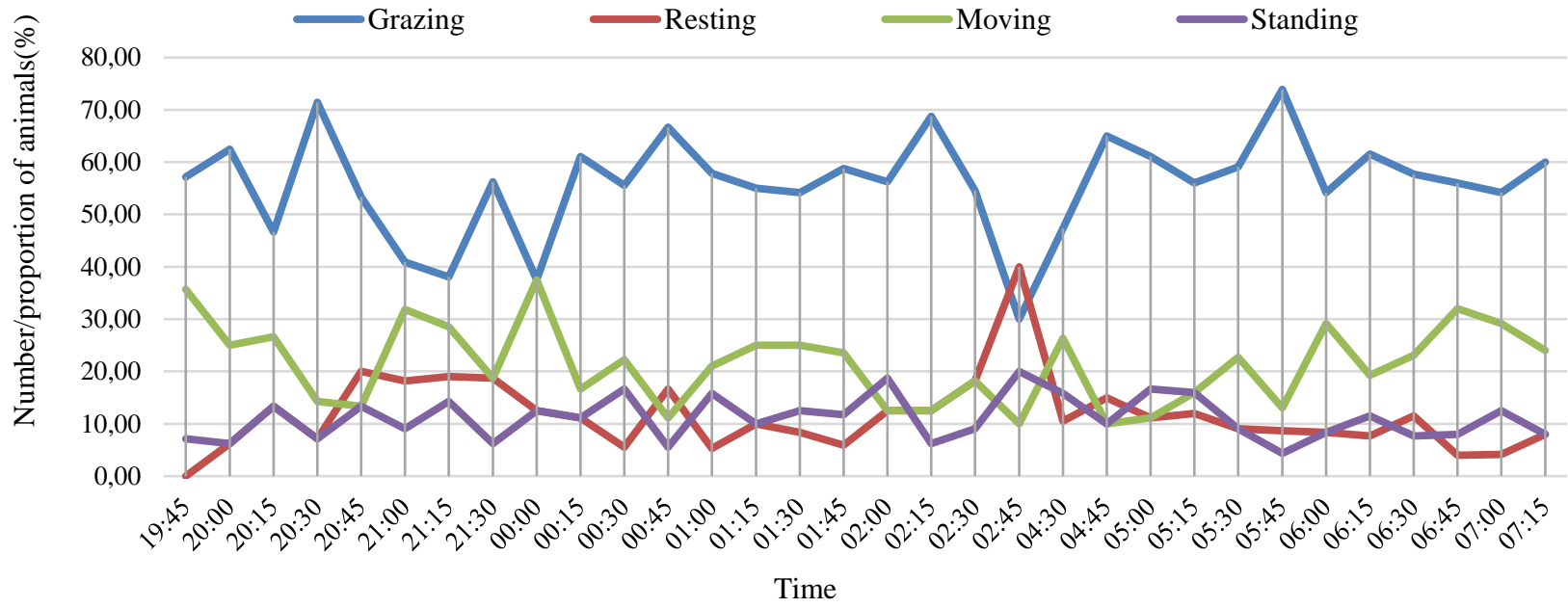

Figure 6. Daily variation of grazing patterns in Ağr1 
Table 1 Percentage of main land-cover categories for both studied paths according to the CORINE land cover information.

\begin{tabular}{c|lrc}
\hline List & \multicolumn{1}{|c}{ CORINE Land Cover (25 km radius) } & Ağr1 & Erzurum \\
\hline 1 & Discontinuous urban fabric & 0.15 & 0.16 \\
2 & Construction sites & 0.00 & 0.01 \\
3 & Non-irrigated arable land & 18.96 & 1.59 \\
4 & Permanently irrigated land & 0.85 & 0.86 \\
5 & Complex cultivation patterns & 2.36 & 3.98 \\
6 & Agriculture land with significant natural vegetation & 9.69 & 7.77 \\
7 & Broad-leaved forest & 0.00 & 1.76 \\
8 & Coniferous forest & 0.00 & 3.52 \\
9 & Mixed Forest & 0.00 & 0.86 \\
10 & Sparsely vegetated areas & 19.64 & 22.04 \\
11 & Transitional woodland-scrub & 0.32 & 11.89 \\
12 & Pastures & 1.12 & 0.00 \\
13 & Natural grassland & 21.06 & 41.71 \\
14 & Beaches, dunes, sands & 0.38 & 0.00 \\
15 & Bare rocks & 3.8 & 3.51 \\
16 & Inland marshes & 0.1 & 0.34 \\
17 & Saline & 17.18 & 0.00 \\
18 & Water courses and bodies & 4.39 & 0.00 \\
\hline
\end{tabular}

Table 2 Variation of grazing patterns in Erzurum highlands

\begin{tabular}{|c|c|c|c|c|}
\hline \multirow{2}{*}{ Pattern } & \multicolumn{3}{|c|}{ Time } & \multirow{2}{*}{ Total } \\
\hline & $19: 45-21: 30$ & $00: 00-02: 45$ & $04: 30-07: 15$ & \\
\hline Grazing (number of animals/\%) & $10(47.6)$ & $12(52.2)$ & $14(66.7)$ & $36(55.4)$ \\
\hline Resting (number of animals/\%) & $3(14.3)$ & $3(13)$ & $2(9.5)$ & $8(12.3)$ \\
\hline Moving (number of animals/\%) & $4(19)$ & $5(21.7)$ & $3(14.3)$ & $12(18.5)$ \\
\hline Standing (number of animals/\%) & $4(19)$ & $3(13)$ & $2(9.5)$ & $9(13.8)$ \\
\hline Total & $21(100)$ & $23(100)$ & $21(100)$ & $65(100)$ \\
\hline
\end{tabular}

$\overline{\chi^{2}: 2.004 \quad \mathrm{P}=0.919}$

Table 3 Variation of grazing patterns in Ağrı highlands

\begin{tabular}{|c|c|c|c|c|}
\hline \multirow{2}{*}{ Pattern } & \multicolumn{3}{|c|}{ Time } & \multirow{2}{*}{ Total } \\
\hline & $19: 45-21: 30$ & $00: 00-02: 45$ & $04: 30-07: 15$ & \\
\hline Grazing (number of animals/\%) & $9(52.9)$ & $10(52.6)$ & $14(60.9)$ & $33(55.9)$ \\
\hline Resting (number of animals/\%) & $2(11.8)$ & $3(15.8)$ & $2(8.7)$ & $7(11.9)$ \\
\hline Moving (number of animals/\%) & $4(23.5)$ & $4(21.1)$ & $5(21.7)$ & $13(22)$ \\
\hline Standing (number of animals/\%) & $2(11.8)$ & $2(10.5)$ & $2(8.7)$ & $6(10.2)$ \\
\hline Total & $17(100)$ & $19(100)$ & $23(100)$ & $59(100)$ \\
\hline
\end{tabular}

$\chi^{2}: 0.726 \quad \mathrm{P}=0.994$

\section{Conclusions}

It is concluded that sheep spent more grazing time and less resting and standing during the whole grazing period. Standing was a residual activity in both study paths. Once animals were heading back to tents to be milked, their grazing activity increased. Further observations together with studies focused on diet selection and animal performances in other periods are needed to detect any seasonal/daily changes in grazing patterns. Those aspects will be useful to adjust the management techniques to a more-efficient use of the natural resources. A deeper analysis on the changes of the land cover along time will help to evaluate the potential of these transhumant activities in the future.

\section{Acknowledgement}

We deeply thank to Dr. Rocio Rosa Garcia and her colleague for their valuable contribution to the paper.

\section{References}

Aldezabal A, Garin I, Garcia-Gonzalez R. 1999. Activity rhythms and the influence of some environmental variables on summer ungulate behaviour in Ordesa-Monte Perdido National Park. Pirineos, 153-154: 145 a 157, JACA. DOI:10.3989/pirineos.1999.v153-154.110.

Anonim. 2017. Ağrı İl Tarım ve Orman Müdürlüğü Çayır Mera ve Yem Bitkileri Şube Müdürlüğü yazılı belgesi, Ağrı.

Anonim. 2017a. Erzurum İl Tarım ve Orman Müdürlüğü Çayır Mera ve Yem Bitkileri Şube Müdürlügü yazılı belgesi, Erzurum.

Brüne CH, Stumpf T. 2004. Grazing of heath and poor sands pasture with sheep and goats. Archiv Fur Tierzucht 47.6; SPI: 18-24 ISSN: 0003-9438

Büttner G, Kosztra B, Maucha G, Pataki R. 2012. Implementation and Achievements of CLC2006. European Environment Agency: Copenhagen, Denmark. https://www.eea.europa.eu/ contact-us (Erişim:15.03.2019)

ESRI 1996. Environmental Systems Research Institute. Arcview GIS: The geographical information system for everyone. Environmental Systems Research Institute, New York, USA http://www.istc.int/en/institute/12791 (Erişim:18.03.2019) 
Delagarde R, Lamberton Philippe. 2015. Daily grazing time of dairy cows is recorded accurately using the Lifecorder Plus device. Appl. Anim. Behav. Sci. 165, 25-32. https://doi.org/10.1016/j.applanim.2015.01.014

FAO. 2016. Befs Assessment for Turkey. Sustainable bioenergy options from crop and livestock studies. FAO. ISBN 978-92109513-3

Fischer A, Schalitz G, Behrendt C .2007. Breed-specific classification potentials of sheep in different grassland biotopes. Arch. Anim. Breed. 50, 174-185. https://doi.org/10.5194/aab-50-174-2007

Hammer EL, Arbuckle BS. 2017. 10,000 Years of Pastoralism in Anatolia: A Review of Evidence for Variability in Pastoral Lifeways. Nomadic Peoples 21, No: 2 214-267(54). DOI: 10.3197/np.2017.210204

Koc A, Schacht WH, Erkovan HI. 2015. The History and Current Direction of Rangeland Management in Turkey. Rangelands, 37(1):39-46. The Society for Range Management. DOI:10.1016/j.rala.2014.12.005

Loridas A, Mountousis I, Roukos C, Yiakoulaki M, Papanikolaou K. 2011. Grazing behavior of the Greek breed of sheep "Serres" in lowland and mountainous pastures. Archiv Tierzucht 54: 2, 165-176. Leibniz Institute for Farm Animal Biology, Dummerstorf, Germany. ISSN 0003-9438. DOI: 10.5194/aab-54-165-2011
Rosa García R, Fraser MD, Celaya R, Ferreira LMM, García U, Osoro K. 2013. Grazing land management and biodiversity in the Atlantic European heathlands: a review. Agroforestry Systems, Volume 87, Issue 1, pp 19-43. DOI 10.1007/s10457-012-9519-3.

Sabanc1 CO. 2012. Role and management of permanent grasslands. 14th Meeting of the FAO-CIHEAM Interregional Cooperative Research and Development SubNetwork on Mediterranean Pastures and Fodder. 3 to 6 October 2012, p: 285-293, Samsun, Turkey.

Sarlis GP. 1998. Range Management. Part 1. A. Stamoulis Press, Athens, Greece, 341. DOI: 10.5194/aab-54-165-2011.

Sayar MS, Han Y, Basbag M, Gul I, Polat T. 2015. Rangeland improvement and management studies in the southeastern Anatolia region of Turkey Pak. J. Agri. Sci., Vol. 52, 9-18.

Shinde AK, Karim SA, Patnayak BC, Mann JS. 1997. Dietary preferences and grazing behavior if sheep on Cenchrus ciliaris pasture in semi-arid region of India. Small Rumin. Res. 26, 119-122.

Squires VR. 1975. Social behaviour in domestic livestock: The basis for improved animal husbandry. Appl. Anim. Ethol, 177-184. PMID: 11376835

Ueda Y, Akiyama F, Asakuma S, Watanabe N. 2011. Technical note: The use of a physical activity monitor to estimate the eating time of cows in pasture. J. Dairy Sci. 94 (7): 34983503. DOI: 10.3168/jds.2010-4033. PMID:21700037 